\title{
INTENT IN CRIMINAL CONSPIRACY
}

\section{Albert J. Harno $†$}

In the long category of crimes there is none, not excepting criminal attempt, more difficult to confine within the boundaries of definitive statement than conspiracy. ${ }^{1}$ It covers the field of crimes and makes unlawful agreements among individuals to commit any crime; ${ }^{2}$ it extends to agreements to commit at least some torts ${ }^{3}$ and some breaches of contract, ${ }^{4}$ and, finally, it shades into the horizon with agreements to do acts, which, though not unlawful when done by the parties separately, may, nevertheless, become unlawful ends for those who agree to commit them.

The crime probably was unknown to the early common law. ${ }^{5}$ The first definite trace of it emerged from the enactment of three statutes in the reign of Edward $I^{6}{ }^{6}$ the final one of which, known as the Ordinacio de Conspiratoribus (33 Edward I), was passed in $1304^{7}$

† B. S., IgIr, LL. D., I927, Dakota Wesleyan University; LL. B., I9I4, Yale University ; LL. D., I938, Tulane University; Dean of the College of Law of the University of Illinois since I922 and Provost of the University of Illinois since I93I; author, Cases and Materials on Criminal Law and Procedure (I933, 2d ed. I939); SuPreme Court in Fetony Cases (Illinois Crime Survey) (I929); co-author, Parole AND INDETERMINATE SENTENCE IN IllinoIS (I928); contributor to various legal periodicals.

The writer wishes to acknowledge the assistance of W. D. Guthrie, a senior law student in the University of Illinois.

I. See Harrison, Conspiracy as a Crine and as a Tort in English law (I924) I. "Conspiracy is the most extended of the offenses, being connected with every form of wrong-doing. And the procedure is in some respects difficult, both from its variety, and because the offense itself has not always been well understood." 3 Bisнop, New Criminal Procedure (2d ed. I9I3) \$202.

2. Sayre urges limiting the crime to agreements involving a purpose to commit a crime. See his article: Sayre, Criminal Conspiracy (1922) 35 HARv. L. REv. 393.

3. Harrison, op. cit. supra note $I$ at 9I; 8 Holdsworth, HISTORY of ENGLISH Law (1926) 38I; KeNNY, OUTLines of Criminal LaW (15th ed. 1936) 337. Harrison and Kenny would limit the application of the crime to agreements to commit torts of fraud or malice. Cf. Wilson v. Commonwealth, $96 \mathrm{~Pa}$. 56 (1880).

4. Harrison suggests that combinations to procure a breach of contract are not criminal conspiracies beyond cases where such breaches are criminal in individuals. HARRISON, op. cit. supra note I at 96-99. Kenny takes the position that such combinations are criminal when they are peculiarly injurious to the public. KENNX, op. cit. supra note 3 at 337, citing Vertue v. Lord Clive, 4 Burr. 2472, 98 Eng. Rep. R. 296 (K. B. 1769 ). 29-37.

5. Winfietd, History of Conspiracy and Abuse of Legal Procedure (ig2i)

6. 3 HOLDSWORTH, op. cit. supra note 3 at 40I-405; WINFIEID, op. cit. supra note 5 at $22-28$.

7. This statute provides: "Conspirators be they that do confeder or bind themselves by oath covenant or other alliance that every of them shall aid and support the enterprise of each other falsely and maliciously to indict, or cause to be indicted, or falsely to acquit people, or falsely to move or maintain pleas; and also such as cause children within age to appeal men of felony, whereby they are imprisoned and sore grieved; and such as retain men in the country with liveries and fees for to maintain their malicious enterprises and to suppress the truth; and this extendeth as well to the takers as to the givers. And stewards and bailiffs of great lords, which by their seignory office or power undertake to bear or maintain quarrels, pleas, or debates for other mat-. ters than such as touch the estate of their lords or themselves." 
No precise definition of conspiracy is afforded in these statutes, but the Ordinacio de Conspiratoribus is explicitly directed against combinations or confederacies for false and malicious promotions of indictments and pleas, for embracery and for maintenance. Further, these statutes do not treat of conspiracy as a substantive, crime but enact a writ, which came to be known as the writ of conspiracy, to aid litigants to determine whether their cause of action was redressable. The writ lay only for a conspiracy to indict or appeal for felony; ${ }^{8}$ the conspiracy itself ". . . was incomplete until the party had been actually indicted and acquitted, . . ." 9 It was not until I6rx in the Poulterers' Case, ${ }^{10}$ decided in the Court of Star Chamber, that a mere agreement to commit a crime became a substantive offense. ${ }^{11}$

The Poulterers' Case is a landmark in the history of criminal conspiracy, for it departed from the doctrine that the conspiracy must actually be carried into effect before a writ of conspiracy would lie. The Court of Star Chamber ruled in that case that the agreement was itself indictable though nothing was executed. "And it is true," says Coke in his observations on the case, 12 "that a writ of conspiracy lies not, unless the party is indicted, and legitimo modo acquietatus, for so are the words of the writ; but that a.false conspiracy betwixt divers persons shall be punished, although nothing be put in execution, is full and manifest in our books." A new development in the law stems, in fact, from that decision. The modern crime of conspiracy, says Holdsworth, ${ }^{13}$ "is almost entirely the result of the manner in which conspiracy was treated by the Court of Star Chamber."

Too little, in fact, is known about the development of law under the guiding hand of the Court of Star Chamber. ${ }^{14}$ There can be no doubt, however, that with its establishment a creative and potent factor

8. 3 Holdsworth, op. cit. sipra note 3 at 40I-407; 2 Pollock and Maitland, History of ENGLish LaW (2d ed. I899) 539.

9. HARRISON, op. cit. stipra note I at i3.

I0. 9 Co. Rep. 55b, 77 Eng. Rep. R. 8i3 (Ct. of Star Ch. I6II).

II. 8 Holdsworth, op. cit. supra note 3 at 379 ; 2 STEPHEN, History of the CrimsINAL LAw OF ENGLAND (I883) 227-229; Digby, The Law of Criminal Conspiracy in England and Ireland (1890) $6 \mathrm{~L}$. Q. REv. I29.

I2. Poulterers' Case, 9 Co. Rep. 55b, 56b, 77 Eng. Rep. R. 8I3, 8I4 (Ct. of Star Ch. I6II) cited note Io supra. See comments on the effect of this decision: HARRISON, op. cit. supra note I at I3-I7; 5 HoldswORTH, - op. cit. supra note 3 at 204; WRIGHT, THE LAw OF CRIMINAL Conspiracies and AgreEMENTs (1873) 6-12; Hudson, $A$ Treatise on the Court of Star Chamber, 2 Hargrave, Collectianea. JuRidica (I792) I04. Hudson does not mention the Poulterers' Case. He begins his remarks on conspiracy as developed in the Court of Star Chamber by saying: "I will conclude the particular offences which I shall speak of with this great offence of conspiracy, rarely heard of in former times, but in our age grown frequent and familiar."

13. 8 HOLDSWORTH, op. cit. supra note 3 at 379 .

14. Remarks Jerome Hall in a recent article: "From the sixteenth century well on into the nineteenth extends the third major development : the growth of a bulky body of law dealing with a vast variety of lesser offenses-the misdemeanors. The development of this body of law by the Court of Star Chamber has, as yet, been almost entirely neglected by the historians of the criminal law." Hall, Criminal Attempt-A Study of Foundations of Criminal Liability (I940) 49 Y ALE L. J. 789, 798. 
was introduced into the scene of English judge-made law. It was a strong court that dealt sternly with offenders, and yet in relation to some of its actions Hudson could say that it was a "court rather of mercy than of justice". 15 "Let this then suffice for the dignity of the court," Hudson comments, ${ }^{16}$ "that in the fame, it matcheth with the highest that ever was in the world; in justice, it is, and hath been ever, free from suspicion of injury and corruption; in the execution of justice, it is the true servant of the Commonwealth; and whatsoever it takes in hand to reform, it bringeth to perfection." The Court of Star Chamber made short work of conspiracies to carry on vexatious legal proceedings. It crushed these combinations, says Winfield, ${ }^{17}$ and "withered conspiracy at its root."

But the Star Chamber, once having gained the vantage of a new conception, did not limit its operations to conspiracies to indict; a new field in the criminal law of vast potentialities had been opened up. If these combinations were criminal, why restrict the doctrine to offenses relating to legal proceedings? ${ }^{18}$ What did it matter that historically the crime was closely related to offenses against the administration of justice? ${ }^{19}$ With the decision in the Poulterers' Case a new crime was in the making. It became an inchoate crime similar to attempt." "And just as it punished all kinds of attempts to commit wrongful acts, so, a fortiori, it, [the Star Chamber] punished all kinds of conspiracies to commit the many varied offences punishable either by it or by the common law courts." 21

The Court of Star Chamber, indeed, provided the spark that supplies the vitality for the crime of conspiracy today and that court also injected into the crime an ominous element that ever since has characterized it. The Star Chamber was a fitting institution for that rôle. Its jurisdiction was vague but almost without limit. "To handle the jurisdiction of this high court," observes Hudson, ${ }^{22}$ "I must steer a course full of peril betwixt Scylla and Charybdis." The Court and the King's Council were closely allied and it is difficult to distinguish the offices of one from the other. Hudson says that in the Star Chamber "all offences may be here examined and punished, if it be the king's pleasure," ${ }^{23}$ and that "by the arm of sovereignty, [it] punisheth errors creeping into the Commonwealth, which otherwise might prove dangerous and infectious

I5. Hudson, note 12 supra at 64 .

16. Id. at 22 .

17. WINFIELD, op. cit. supra note 5 at 107, II2.

18. HARRISON, op. cit. silpra note I at 15 .

19. 5 HoldswORTH, op. cit. sipra note 3 at 203.

20. 2 STEPHEN, op. cit. sipra note II at 227.

2I. 5 HoldswORTH, op. cit. supra note 3 at 205 .

22. Hudson, note I2 supra at 49.

23. Id. at 62 . 
diseases, or [it] giveth life to the execution of laws, or the performance of such things as are necessary in the Commonwealth, yea although no positive law or continued custom of common law giveth warrant to it." 24 In another illuminating passage he characterizes the Court as acting as the "curious eye of the state and king's council prying into the inconveniencies and mischiefs which abound in the Commonwealth." 25 "It is these ideas," observes Holdsworth, ${ }^{26}$ "which the common law adopted, when they held that conspiracies to do acts, which were neither crimes nor torts, were indictable." That these acts were contrary to public policy, and that a confederacy to effect them must therefore be treated as a conspiracy, was, he concludes, an idea that "came naturally to the Court of Star Chamber."

But the acceptance of this doctrine, in its broad implications, by the common law courts after the Restoration did not come about without some misgivings. In Starling's Case ${ }^{27}$ it was held that a confederacy by the brewers of London to put down the "gallon trade" by which the poor were supplied and to cause the poor to mutiny against the farmers of the excise was illegal, since to impoverish the farmers of the excise would prevent them from rendering to the King his revenue. A few years later, however, Lord Holt said a conspiracy "is odious in the law", ${ }^{28}$ and in Regina v. Daniell ${ }^{29}$ he sought to limit the implications of Starling's Case and, in fact, to restrict the expanding scope of the crime itself. The gist of the offense in Starling's Case, he said, "was its influence on the publick, and not the conspiracy, for that must be put in execution before it is a conspiracy." 30 That was in I704. In I7I7 Hawkins' Pleas of the Crown was published. In that work the assertion was made that "there can be no doubt, but that all confederacies whatsoever, wrongfully to prejudice a third person, are highly criminal at common law." 31 And four years later in Rex $v$. Journeymen Taylors of Cambridge, ${ }^{32}$ the court said, "a conspiracy of any kind is illegal, although the matter about which they conspired might have been lawful for them, or any of them, to do, if they had not conspired to do it." ${ }^{33}$ These principles, as stated by Hawkins and

24. $I d$. at 107.

25. $I d$. at I26.

26. 8 HOLDSWORTH, op. cit, supra note 3 at 382 .

27. I Sid. 174, 82 Eng. Rep. R. 1039 (1664).

28. Roberts v. Savill, 5 Mod. $405,407,87$ Eng. Rep. R. 733, 734 (I699).

29. 6 Mod. 99, 87 Eng. Rep. R. 856 (1704).

30. Id. at IOO, 87 Eng. Rep. $R$. at 856 .

31. I HawkINS, Pleas of THE CRown (6th ed. I787) 72, §2, p. 348. The authorities cited by Hawkins for this statement give doubtful support. See HARRISON, op. cit. supra note 1 at 25; SAYRe, op. cit supra note 2 at 402; WINFIELD, op. cit. supra note 5 at II7; WRIGET, op. cit. supra note I2 at II, I2, 38. Holdsworth, however, appears to support him on Starling's Case. 8 Holdsworth, op. cit. supra note 3 at 381 .

32. 8 Mod. ro, 88 Eng. Rep. R. 9 (I72I).

33. Id. at ro, Ir, 88 Eng. Rep. R. at ro. 
in the Journeymen Taylors Case, although they were followed by some fluctuation in views, were the ones that prevailed in later law. ${ }^{34}$

\section{The Criminal Intent}

An indictment for conspiracy, said Denman, C. J., in Rex $v$. Jones, $_{\text {, }}^{35}$ "ought to charge a conspiracy, either to do an unlawful act, or a lawful act by unlawful means." This concept was later enlarged upon and drafted into a definition of the substantive crime by Willes, J., in Mulcahy v. Regina, as follows:

"A conspiracy consists not merely in the intention of two or more, but in the agreement of two or more to do an unlawful act, or to do a lawful act by unlawful means. So long as such a design rests in intention only, it is not indictable. When two agree to carry it into effect, the very plot is an act in itself, and the act of each of the parties, promise against promise, actus contra actum, capable of being enforced, if lawful, punishable if for a criminal object or for the use of criminal means." 38

Two ideas-one baffling but explored repeatedly; the other also baffling but almost unexplored-stem from the definition quoted from the Mulcahy Case. The first involves the meaning of the word "unlawful." A conspiracy is a confederation of two or more persons to accomplish by concerted action an unlawful purpose, or a lawful purpose by unlawful means. That is the substance of the accepted definition. But what is the meaning and scope of the word "unlawful"? That question has given rise to long, and, at times, heated controversy. "In various cases," says Stephen, ${ }^{37}$ "the definition that a conspiracy is an agreement to do an unlawful act was held to mean something more than an agreement to do an act which is in itself criminal when done by a single person, the word 'unlawful' being used in a sense closely approaching to immoral simply, and amounting at least to immoral and at the same time injurious to the public." It is not the purpose of this study to follow in detail the meaning of the word "unlawful." That question will be explored only when it touches the other idea, the intent concept, involved in the Mulcahy definition. It is to the intent factor in conspiracy that we now direct our attention.

34. 8 Holdsworte, op. cit. supra note 3 at $38 \mathrm{r}$.

35. 4 B. \& Ad. 345, 349, IIo Eng. Rep. R. 485, 487 (I832). Parke, J., makes a similar statement in this case: "This indictment ought to have shewn a conspiracy to do an unlawful act, or to do a lawful act by unlawful means." Ibid.

36. L. R. 3 Eng. \& Ir. App. 306, 317 (1868). "A conspiracy is constituted by an agreement, it is true, but it is the result of the agreement, rather than the agreement itself, just as a partnership, although constituted by a contract, it is not the contract, but is a result of it. The contract is instantaneous, the partnership may endure as one and the same partnership for years. A conspiracy is a partnership in criminal purposes." Holmes, J., in United States v. Kissel and Harned, 218 U. S. 60I, 608 (19I0). See also, Marino v. United States, $9 \mathrm{I}$ F. (2d) 69I, 694 (C. C. A. 9th, I937).

37. 2 Stephen, op. cit. supra note in at 229 . 
It is a curious fact that in all that has been written about criminal conspiracy there is scant mention of intent. It would seem that the intent idea might well have provoked the very conception of the crime. May we indulge for a moment in speculation? The intent element is an important factor in crime, but no one is punished for the harboring merely of a criminal intent. There must be an act giving adequate expression to the intent. Roe has the intent to murder Forises. Roe, though he has in fact given expression to his intent to murder Forbes, is guilty of no crime. But surely Roe in holding that intent becomes a person of concern to the community, and when his intent becomes known to Forbes and others a disturbing apprehension is likely to be raised in their minds. Roe has become a factor of potential danger to the community. Now, Doe likewise may have an intent to murder Forbes, and he also may have given expression to it. The potential danger to Forbes and the community is thus increased, but neither Roe nor Doe is guilty of a crime. Roe and Doe may even communicate their intentions to each other, and still there is no crime. But once they unite their intentions through agreement to make a common cause of killing Forbes, a crime is committed. ${ }^{38}$ The transaction is fait accompli; Roe and Doe are indictable for criminal conspiracy.

Now, what is it that makes this a crime? Two factors are here to be considered, namely, the intent or purpose of Roe and Doe, and their act of agreement. The confederation of Roe and Doe through agreement to commit an anti-social act, no doubt, increases their potential dangerousness to the community. But this agreement is so slight an act that, taken by itself, it seems fairly insignificant. It is only as we consider this act in relation to the threat Roe and Doe present to the peace of the community because of the intent they hold that a rationale for the crime can be found. The potential danger to the community is heightened through the agreement, that is, through the act of uniting their intentions, but the full significance of the peril they hold for others can only be understood in terms of their purpose or intent. The intent of each held separately makes each of them potentially dangerous but not a criminal. Their act of agreement, though but a factor of slight added significance, marks them criminals.

Something of this analysis may have been in Justice Willes' mind when he wrote the statement quoted from the Mulcahy Case. ${ }^{39}$ So long, said he, as the "design rests in intention only, it is not indictable." The conspiracy, he observes, "consists not merely in the intention of two or more," but in their "agreement." The emphasis perhaps would

38. In some jurisdictions an overt act beyond the mere agreement is necessary. supra.

39. Mulcahy v. Regina, L. R. 3 Eng. \& Ir. App. 306, 3I7 (I868) cited note 36 
have been better placed had he said, "the conspiracy consists not merely in the agreement of two or more but in their intention." Lord Chelmsford's language in the same case is equally significant. "It is a mistake," he contends, "to say that conspiracy rests in intention only." And he goes on to say:

"It cannot exist without the consent of two or more persons, and their agreement is an act in advancement of the intention which each of them has conceived in his mind. The argument confounds the secret arrangement of the conspirators amongst themselves with the secret intention which each must have previously had in his own mind, and which did not issue in act until it displayed itself by mutual consultation and agreement." 40

The Mulcahy Case represents one of the rare instances in which a court has taken the intent element clearly into account in stating a rationale for the crime. Winfield found that the defendants to a writ of conspiracy were not liable unless they acted "falsely and maliciously." But, he added, "We shall look in vain in the earlier law for any minute dissection of either term." 41 So is the situation with the modern crime. Bishop speaks of conspiracy as a "corrupt agreeing." "Corrupt," he says, "denotes an evil purpose, not restricted as to the form of the evil." ${ }^{42}$ According to Wharton "joint evil intent" is necessary to constitute the offense. The confederation, he continues, "must be corrupt." "43 Many statements of similar import are found in the decisions of the courts. ${ }^{44}$ Not infrequently the language shifts to the concept of motive. The motive, it is said, must be "corrupt." The reference to motive is often found in decisions upholding the doctrine that a conspiracy charge will lie, though the contemplated act if done by an individual would have been lawful. ${ }^{45}$ This view and the reasons sup-

40. Id. at 328. WRIGRT, op. cit. supra note I2 at 6-7, expresses a similar idea. $\mathrm{He}$ says: "The modern law of conspiracy has grown out of the application to cases of conspiracy . . . of the early doctrine that since the gist of crime was in the intent, a criminal intent manifested by any act done in furtherance of it might be punishable, although the act did not amount in law to an actual attempt. In accordance with this view it was determined . . . that although the crime of conspiracy, properly so called, was not complete . . yet the agreement for such a conspiracy was indictable as a substantive offence, since there was a criminal intent manifested by an act done in furtherance of it, viz., by the agreement."

"Here as everywhere in our law," says KeNNY, op. cit. supra note 3 at 335, "bare intention is no crime. . . It is not mere intention, but the announcement and acceptance of intentions."

And see analysis in State v. Glidden, 55 Conn. 46, 8 Atl. 890 (1887).

4T. WINFIELD, op. cit. supra note 5 at 66 .

42. 2 BISHOP, CRIMINAL LAW (9th ed. I923) \$§ I71, I72.

43. 2 Wharton, Criminal Law (I2th ed. I932) $\$$ I 608 .

44. See Morrison v. California, 291 U. S. 82 (I934); Grandbouche v. People, I04 Colo. 175, 89 P. (2d) 577 (1939); People v. Flack, I25 N. Y. 324, 26 N. E. 267, II L. R. A. 807 (I $89 \mathrm{I})$.

45. People v. Klaw, 55 Misc. 72, I06 N. Y. Supp. 34I (Ct. Gen. Sess. 1907); People v. Flynn, II4 App. Div. 578, I00 N. Y. Supp. 3I (Ist' Dep't Igo6), aff'd I89 N. Y. I80, 82 N. E. I69 (I907); Mifflin v. Commonwealth, 5 W. \& S. 461 (Pa. IS43); Commonwealth v. Carlisle, Bright. 36 ( $\mathrm{Pa}$. I821). 
porting it are well stated in a penetrating analysis by Justice Gibson in Commonwealth ex rel. Chew $v$. Carlisle. ${ }^{46}$ "The unsettled state of the law of conspiracy," he observes, "has arisen . . . from a gradual extension of the limits of the offence." There was little or no difficulty, he points out, in pronouncing the confederation criminal where the object was to do a criminal act or to accomplish a lawful end by criminal means. But, he continues:

"When the crime became so far enlarged as to include cases where the act was not only lawful in the abstract, but also to be accomplished exclusively by the use of lawful means, it is obvious that distinctions as complicated and various as the relations and transactions of civil society, became instantly involved. . . . It will therefore be perceived that the motive for combining or, what is the same thing, the nature of the object to be attained as a consequence of the lawful act is, in this class of cases, the discriminative circumstance. Where the act is lawful for an individual, it can be the subject of a conspiracy, when done in concert, only where there is a direct intention that injury shall result from it, or where the object is to benefit the conspirators to the prejudice of the public or the oppression of individuals, and where such prejudice or oppression is the natural and necessary consequence."

There are, indeed, two types of intent in every conspiracy. These always shade into each other and often there is no practical purpose served in distinguishing them. In a number of instances, however, legal consequences hinge on which of the two is involved and, when that is true, it becomes essential that they be distinguished. Since every conspiracy involves an agreement, it is necessary to establish through sufficient evidence that each of the parties charged had an intent to enter into that agreement. The question here involved is similar to that which arises in connection with the establishment of any partnership. The issue is, was there a meeting of the minds? Did the separate intentions of each of the parties meet on common ground to effect an agreement? Once the agreement is established, the next question is whether the purpose agreed upon involves a criminal intent. The inquiry here is, was that common intent criminal? The issue on the first intent thus is whether each of the persons charged is a party to the agreement; the issue on the second is whether the common intent as united through agreement carries criminal consequences. This distinction appears to be of considerable importance and it is passing strange that it has not been stressed by writers on conspiracy. May we now carry this distinction forward with concrete cases.

46. Commonwealth v. Carlisle, Bright. 36, 38-39 (Pa. I82x) cited note 45 supra. 


\section{The Intent to Agree in Conspiracy}

It is difficult to make an analysis of the elements of conspiracy because the crime is so predominantly mental in composition. The act in most crimes is obvious. A man strikes another or takes his property. In conspiracy the act of the individual lies in bringing his state of mind through express statement or by implication to the attention and understanding of another, and in his coming to an agreement with that other. To be sure, contracts are made in that way and they entail legal consequences. But crimes ordinarily involve more physical action. In conspiracy the act that brings a person to one mind with another is also the very act that makes his behavior criminal. The act is accomplished when he brings his intention into concurrence with that of the other. That makes the agreement, and if the purpose or intent of the agreement is unlawful, a crime is committed. ${ }^{47}$ It is therefore a matter of primary concern to determine whether he intended to become a party to the agreement. ${ }^{48}$

As a matter of criminal pleading the question narrows down to this. The prosecution must allege, and prove as laid, the agreement on which the criminal charge is based. ${ }^{49}$ This means, among other things, that as against a particular defendant, it must allege and prove that he was a party to the conspiracy charged. Forbes and Roe are charged with a conspiracy to obtain money from Doe by means of false pretenses. The evidence shows that Forbes acted with bad intent, but that Roe, though he took part in the transaction, had no intent to defraud Doe. The prosecution has failed to prove Roe guilty of the conspiracy. It has failed to prove that he was a party to the agreement charged. ${ }^{50}$ In a federal case, ${ }^{51}$ Davidson, Brummell, Weber, Gillette and Latimer were charged with a conspiracy to violate the National Motor Vehicle Theft Act. ${ }^{52}$ The evidence established that the car was stolen in Okla-

47. In some jurisdictions, to be sure, an overt act must also be committed.

48. That there has been considerable confusion on the agreement factor see, Cousens, Agreement as an Element in Conspiracy (1937) 23 VA. L. Rev. 898.

49. See WrigHr, op. cit. supra note 12 at 72-73; Fuller v. United States, Ir4 F. (2d) 698 (C. C. A. 9th, I940); Wong Tai v. United States, 273 U. S. 77, 8I (1926); United States v. Cruikshank, 92 U. S. 542, 558-559 (1875).

50. See Evans v. People, go Ill. 384 ( 1878 ). The prosecution would fail also against Forbes, since he could not be guilty of conspiracy by himself. See also, Morrison v. California, 29 I U. S. 82 (I934) cited note 44 sipra; Commonwealth v. Benesch, 290 Mass. I25, 194 N. E. 905 (I935); State v. Dougherty, 88 N. J. L. 209, 96 Atl. 56 (I9I5).

5I. Davidson v. United States, 6I F. (2d) 250 (C. C. A. 8th, 1932).

52. 4I Stat. 324, 18 U. S. C. A. \$ 408 (Supp. 1925). The pertinent language of this section reads: "Whoever shall transport or cause to be transported in interstate or foreign commerce a motor vehicle, knowing the same to have been stolen, . . . Whoever shall receive, conceal, store, barter, sell, or dispose of any motor vehicle, mov: ing as, or which is a part of, or which constitutes interstate or foreign commerce, knowing the same to have been stolen,..." 
homa and transported to Kansas City, Missouri. The statement continues in the language of the court: ${ }^{53}$

"But there is an utter absence of any testimony that Davidson and Brummell were parties to any conspiracy as alleged in the first count of this indictment. The fact that in selling this car Davidson and Brummell aided the conspirators is not sufficient. It is necessary that there be proof of an unlawful agreement, either express or implied. . . . There is no evidence that indicates any participation on their part with knowledge of the conspiracy. . . . The evidence would warrant the view that these defendants, Davidson and Brummell, conspired with Gillette to sell a stolen car, but that conspiracy is not the one charged in the indictment. There is no evidence nor any circumstance whatsoever which even remotely indicates that these two defendants had any knowledge that this was an interstate car, or that Gillette was engaged in transporting a car or cars in interstate commerce." 54

To prove a conspiracy it must be shown that the accused had knowledge of it, but mere knowledge or even approval of an unlawful design are not in themselves sufficient. The evidence must establish that there was unity of intent on the part of two or more persons to accomplish the end charged. That which gives to the crime its "distinctive character", said a Pennsylvania court, "is unity of purpose, unity of design, focalization of effort upon a particular project by the persons named in the indictment." ${ }^{55}$ In State $v$. King ${ }^{56}$ the accused, who had a grievance against $W$, told $D$ if he would whip $W$ someone would pay his fine. $D$ replied that he did not want anyone to pay his fine, that he had a grievance of his own against $W$ and that he would whip him at the first opportunity. Shortly after that $D$ did beat $W$ very severely. The accused did not assist $D$ but, as the latter was withdrawing from the assault, the accused indicated his satisfaction with what $D$ had done. These facts did not establish a criminal conspiracy. There was no proof, said the Court, "of any concert of action, or of any understanding or agreement therefor." "The mere knowledge," it went on to say, "acquiescence, or approval of an act, without co-

53. Davidson v. United States, 6I F. (2d) 250,253 (C. C. A. 8th, 1932) cited note $5 I$ sipra.

54. ". . . To establish a conspiracy to violate a criminal statute the evidence must convince that the defendants did something other than participate in the substantive offense which is the object of the conspiracy. There must, in addition thereto, be proof of the unlawful agreement. ${ }^{\circ}$ " Linde v. United States, I3 F. (2d) 59 , 6I (C. C. A. 8th, I926). See also, United States v. Falcone, 6I Sup. Ct. 204 (U. S. I940), affirming United States v. Falcone, 109 F. (2d) 579 (C. C. A, 2d, I940) ; Dickerson v. United States, I8 F. (2d) 887 (C. C. A. 8th, r927); People v. Friedlander, 280 N. Y. 437, 2 I N.E. (2d) 498 (1939); United States v. Cerecedo, 6 Porto Rico Fed. 626 (1914). Cf. Pattis v. United States, I7 F. (2d) 562 (C. C. A. 9th, 1927); United States v. Pecoraro, II5 F. (2d) 245 (C. C. A. 2d, 1940).

55. Commonwealth v. Zuern, I6 Pa. Super. 588, 600 (Igor).

56. 104 Iowa 727,74 N. W. 691 (I898). 
operation or agreement to co-operate, is not enough to constitute the crime of conspiracy." $57 \quad D$ had the intent, it is to be observed, to commit an assault on $W$. The accused probably had a like intent or, at least, was willing to enter into a scheme which contemplated an assault on $W$. But $D$ did not intend to make a common cause with the accused of an assault on $W$. The evidence failed to establish an agreement.

It is not necessary, as was held by Justice Sutherland in United States $v$. Manton, ${ }^{58}$ that "each of the conspirators shall participate in, or have knowledge of, all its operations." A person may, indeed, "join at any point in its progress and be held responsible for all that may be or has been done." 59 But this is not inconsistent with the view here stressed that it is of the essence of conspiracy for there to be knowledge on the part of the individual charged of the unlawful design; that he intend to associate himself in the promotion of that design; that he give expression to that intent to his co-conspirators (or co-conspirator) either by words or conduct, and that he be accepted by them (or him) às a co-participant. ${ }^{60}$ "At times," says Judge Learned Hand, "it seemed to be supposed that, once some kind of criminal concert is established, all parties are liable for everything anyone of the original participants does, and even for what those do who join later." $\mathrm{He}$ continues:

"Nothing could be more untrue. Nobody is liable in conspiracy except for the fair import of the concerted purpose or agreement as he understands it; if later comers change that, he is not liable for the change; his liability is limited to the common purposes while he remains in it. The confusion is perhaps due to the fact that everything done by the conspirators-including the declarations of later entrants-is competent evidence against all, so far as it may fairly be thought to be in execution of the concert to which the accused is privy, though that doctrine too is often abused." 61

57. Id. at $729,74 \mathrm{~N}$. W. at 692 .

58. 107 F. (2d) 834,848 (C. C. A. 2 d, 1938 ).

59. Ibid.

60. United States v. Barrett, 65 Fed. 62 (C. C. S. C. I894) ; United States v. Koch, II3 F. (2d) 982 (C. C. A. 2d, 1940).

61. United States v. Peoni, 100 F. (2d) 401,403 (C. C. A. 2d, 1938).

Judge Hand's reference, in the latter part of the statement quoted above, to what is done and said by a conspirator as being competent evidence against the others, has an important bearing on the question here under consideration, viz., whether the person charged is a party to the agreement. What Forbes does or says ordinarily does not bind Roe. But if Forbes and Roe are united in a common enterprise, what Forbes then does or says in the furtherance of that enterprise is competent evidence against Roe. As a matter of procedure in the introduction of evidence, however, a foundation must first be laid. Before Forbes' acts or statements are admitted against Roe, it must be established that there was a common enterprise between them and that Forbes' acts or statements were in its furtherance. Hence all the factors stressed above on the essentials of an agreement are here involved. See Solomon v. State, I68 Tenn. I80, 76 S. W. (2d) 33T (I934). 


\section{The Common Intent in Conspiracy}

The crime of conspiracy, as we have observed, is heavily mental in composition. In the majority of crimes it is the act with which the law is most concerned; the intent in those crimes is a factor that must be established as a condition to holding the accused criminally responsible for the act. In conspiracy the stress is on the intent element. The danger lurks in the intent. It is present when one person harbors an intent to do an anti-social act, and it is greater when two or more hold it separately. Their behavior becomes criminal when they agree to make a common cause of committing that act. The agreement, it is said, is the act in criminal conspiracy. In truth, it is but a step toward the accomplishment of another act, the commission of which the state wishes to prevent. The agreement is a step toward the accomplishment of a specific anti-social act. Turner has pointed out, ${ }^{62}$ while "it is a broad rule of our Common Law that mens rea can be either the state of mind of the man who intends the consequences of his conduct, or the state of mind of the man who realizes what the consequences of his conduct may be and who . . . is reckless or indifferent to them," that the crime of attempt requires a "mens rea of the former kind exclusively." So it is with criminal conspiracy. Criminal conspiracy involves a specific intent to commit a particular act, the perpetration of which the state desires to forestall. As a problem in procedure, to establish a criminal conspiracy the state must prove an agreement on the part of two or more persons, and it must prove that the common intent flowing from that agreement was specific and was criminal.

That criminal conspiracy must involve a specific intent becomes apparent when the essential attributes of the crime are analyzed. When Forbes and Roe agree to accomplish some anti-social act, the only factor added to the intents they previously had held separately is their agreement to unite their intentions into a common purpose. But when we speak of the purpose of their agreement, we must mean that Forbes and Roe have set for themselves some end to be attained. Though their agreement is the act that marks their behavior criminal, the act of agreement is, at most, inchoate: The behavior that draws punishment is still predominantly mental. Their criminal conduct lies in their common design or purpose to commit a further act. It is that further act with which the state is concerned. And it is because Forbes and Roe have marked themselves as persons who are likely to commit that further act that the protective devices of the state go into action against them. But the further act we are speaking about must necessarily be

62. Turner, Attempts to Commit Crimes (I934) 5 CAMB. L. J. 230, 235. 
specific and Forbes and Roe must have the intent through concert of action to commit that specific act.

In view of the wide field over which the crime of conspiracy ranges and the many varying factors it involves, the task of rationalizing the decisions bearing on the crime is exceedingly difficult. What Justice Gibson said over a century ago about the unsettled state of the law of conspiracy ${ }^{63}$ is just as true today as it was then, with this difference: since that time hundreds of decisions, as yet unconceived when he wrote, have made their appearance only to complicate and unsettle the law still further. That a specific intent must be proved is clear. ${ }^{64}$ It is not the agreement in conspiracy that causes the mischief; it is what the agreement portends. As said by a New York court, the state of mind in conspiracy "does not refer to the act of conspiring, but to the fruits of the conspiracy." 65 Applying this concept to a civil case, an English court observed that "as a rule it is the damage wrongfully done, and not the conspiracy, that is the gist of actions on the case for conspiracy." 66 But assuming that we are dealing with a specific intent, what are the implications of that assumption? And are there special attributes of the specific intent in conspiracy that do not characterize it in the texture of other crimes?

The verbalisms of the courts describing the intent in conspiracy are well-nigh terrifying. The decisions abound in statements that the intent must be "evil", "wicked", or "corrupt"; that the federation must be "corrupt", and that the "motives" of the actors must be "evil" or "corrupt". In some instances the "good faith" of the parties is mentioned as a factor establishing a defense; in others, acting with "just cause" is a defense. The opinion has been advanced, while criminal conspiracy involves a specific intent, that this intent "is only satisfied if the defendants have made their agreement (I) with actual knowledge that the act contemplated is unlawful, or (2) with intent to do an act so obviously anti-social in character that they reasonably should have known it to be unlawful." 67 We shall proceed with this study on the assumption that we are dealing with a crime in which the intent element is the gist; that that intent is specific, and that the decisions, though not all of them, can be rationalized on that assumption.

63. Commonwealth v. Carlisle, Bright. 36 ( $\mathrm{Pa}$. r821) cited note 45 supra. In a later case, Miffin v. Commonwealth, 5 W. \& S. $46 \mathrm{I}, 462$ (Pa. I843) cited note 45 supra, Justice Gibson said: "The law of conspiracy is certainly in a very unsettled state. The decisions have gone on no distinctive principle ; nor are they always consistent."

64. But cf. Chadwick v. United States, I4I Fed. 225 (C. C. A. 6th, I905); People v. Cohn, 358 Iil. 326 , I93 N. E. I50 (I934).

65. Elkin v. People, 28 N. Y. I77, I79 (I863).

66. Mogul Steamship Co., Ltd. v. McGregor, 23 Q. B. D. 598, 616 (1889).

67. Note, Criminal Conspiracy (I924) 38 Harv. L. Rev. 96, 97. 
Before going further, however, with the study of the intent factor in conspiracy, may we briefly examine the characteristics of the specific intent element as we find it in crimes other than conspiracy. "Whenever a specific intent is an element of an offense," observed the California District Court of Appeal in a burglary case, 68 "the existence of the intent must be proved as a fact, and is not presumed from the commission of an unlawful act." In an Alabama case, ${ }^{69}$ where the accused was charged with an assault with intent to murder, the court emphasized the fact that the intent charged reached "beyond the act done." The defendant, it said, "is indicted not merely for what he has effected, but for what he intended to effect; not only for his act, but for the intent with which he did that act." $\mathrm{He}$ ought not to be convicted, it continued, "unless his intent in fact was the same that is laid in the indictment." The generally-accepted rule of the common law that neither ignorance nor mistake constitutes a defense to a criminal charge admits one well-defined exception. When a specific intent "is a requisite element of the offense, and such intent is negatived by ignorance or mistake, it is held that the defendant shall not be convicted, . . ." ro

When an offense involving a specific intent is charged, the rule is well established in criminal pleading that the intent requisite for the crime must be alleged. ${ }^{71}$ When the charge is for criminal conspiracy, it is said to be essential that the purpose of the conspiracy be alleged and that the averment show that that purpose was one for which it is criminal to agree. ${ }^{72}$ As broadly stated in an opinion by the Supreme Court of the United States, ${ }^{73}$ "when the criminality of a conspiracy consists in an unlawful agreement of two or more persons to compass or promote some criminal or illegal purpose, that purpose must be fully and clearly stated in the indictment; while if the criminality of the offence consists in the agreement to accomplish a purpose not in itself criminal or unlawful, by criminal or unlawful means, the means must be set out." In Wood $v$. State ${ }^{74}$ the accused were members of a board of chosen freeholders for the County of Camden. They were charged with combining to vote a sum of money from the county funds to be paid to a third person who, it was alleged, was not lawfully entitled to it. In holding that the indictment should be quashed, the court said

68. People v. Flores, 86 Cal. App. 235, 237, 260 Pac. 822, 823 (I927).

69. Ogletree v. State, 28 Ala. 693, 701 (1856). See also State v. Thomas, $127 \mathrm{La}$. 576,53 So. 868 (1910).

70. Keedy, Ignorance and Mistake in the Criminal Lazi (I908) 22 HARv. L. Rev. 75, 89. In this article Professor Keedy has made an exceptionally able and penetrating analysis of this subject.

7I. 2 Bishop, NEW CRIMINAL Procedure (2d ed. I9I3) $\$ \$ 521,523$.

72. Commonwealth v. Hunt, 4 Metc. III (Mass. I842).

73. Pettibone v. United States, I48 U. S. 197, 203 (1893).

74. 47 N. J. L. $46 \mathrm{I}$, I Atl. 509 (1885). 
that "the actual criminal intention belongs to the definition of conspiracy and must be shown to justify a conviction"; that the indictment did not charge a "corrupt combination", nor "show a corrupt purpose," and that it did not show "the defendants knew that he [the third person] was not entitled" to the money. ${ }^{75}$ In short, the indictment did not aver a common purpose or intent to do an unlawful act.

On the question of the type and sufficiency of the evidence necessary to support the allegation in an indictment for conspiracy, we find the courts holding, as they do on other crimes involving a specific intent, that the intent averred in the charge must be proved. In State $v$. Parento, ${ }^{76}$ where the charge was that the defendants had conspired to represent to others that they could for a consideration "fix" some cases for them, the court emphasized the fact that the evidence must support the intent charged, and though the circumstantial evidence was strong, it did not, in the judgment of the court, establish guilt beyond a reasonable doubt. In People v. Mader the court declared ${ }^{77}$ that it is not sufficient to sustain a conviction on a particular charge in conspiracy "to prove that the defendant is guilty of some other charge or of generally bad and criminal conduct, but the proof must establish his guilt of the particular charge in the indictment." In Commonwealth $v$. Harley ${ }^{78}$ the court found a fatal variance in that the charge was for a conspiracy to defraud a specific person named in the indictment and the evidence showed an intent to cheat the public generally, or any person who might fall in the way of the conspirators. "The government having elected," said the court, "to set forth in the indictment a special intent to defraud Stephen W. Marsh, as the object of the conspiracy on the part of both the conspirators . . . that allegation was a material one, and the government was bound to establish it by proof." 79

In State $v$. Clemenson, ${ }^{80}$ where the defendants were charged with conspiracy to commit adultery with a woman named in the indictment, the conviction was reversed because the evidence did not establish that the defendants knew that she was a married woman. "Without such knowledge," said the court, "it is not perceived how they could have conspired with defendant to have committed this particular crime." 81

75. Id. at 464 , I Atl. at $5 \mathrm{II}$.

76. 135 Me. 353, I97 Atl. 156 (1938).

77. 313 III. 277,285, I 45 N. E. 137, I40 (1924). See also Commonwealth v. Wickenheiser, 45 Dauphin Co. Rep. 410 (Pa. I938).

78. 7 Metc. 506 (Mass. I844).

79. Id. at 5Io. See also, Lowell v. People, 229 I11. 227,82 N. E. 226 (1907).

80. 123 Iowa 524, 99 N. W. 139 (1904).

81. Id. at 527, 99 N. W. at I40. See also, State v. Mitchell, 149 Iowa 362, I28 N. W. 378 (1910). 
This doctrine was carried a step further in Salas $v$. United States. ${ }^{82}$ The defendant was convicted in the trial court of conspiring with two others, Bermudez and Burke, to defraud the United States. ${ }^{83}$ The government proved that the three had made an agreement to share equally in the profits to be made from the sale of tobacco by Salas and Bermudez to the Panama Railroad Company. Burke was the manager of the commissary department of the railroad company, and according to the agreement, he was to order and pass on the tobacco sold to the company. The railroad company was owned and operated by the United States. The Circuit Court of Appeals held that the combination proved by the evidence, though it may have been pointed to defraud the railroad company, did not defraud the United States. The court then went on to say: ${ }^{84}$

"If, however, it be conceded that Burke, though on the payroll of and paid by the railroad company, was an officer of the United States and acting as such in the purchase of tobacco, the agreement as proved did not, in our opinion, satisfy the requirements of the case. The statute clearly contemplates that the parties shall intend to defraud the United States and the indictment charged such an intent. The government offered in evidence a large mass of documents to prove the relations of the railroad company and the Commission and that the railroad company was a mere governmental department. We discover nothing in the evidence to justify the jury in finding, at least beyond a reasonable doubt, that Salas knew anything about these complicated relations, or that the United States was buying this tobacco through the railroad company. Indeed, Burke himself, who testified as a witness for the government, said that he considered himself to be an employe of the railroad company and not of the United States."

Some of the instances cited may appear to be mere over-refinements in the law. They are typical, nevertheless, of the strictness with which courts scrutinize procedures dealing with offenses in which the intent factor is the substance. The pleadings must aver the requisite intent for the crime, and the evidence must support the allegations to a nicety. Moreover, the prosecution must show that the accused intended to do an unlawful act. The question here is not merely, did he intend to do an act forbidden by law, but did he intend to do an act which he

82. Salas v. United States, 234 Fed. 842 (C. C. A. 2d, 1916).

83. The indictment was brought under Section 37 of the Criminal Code, 35 STat. I096 (I909), I8 U. S. C. A. $\$ 88$ (1927), which reads: "If two or more persons conspire either to commit any offense against the United States, or to defraud the United States in any manner or for any purpose, and one or more of such parties do any act to effect the object of the conspiracy, each of the parties to such conspiracy shall be fined. . " supra.

84. Salas v. United States, 234 Fed. 842,845 (C. C. A. 2d, I9I6) cited note 82 
knew to be unlawful? This, it will be observed, accords with and fits into the rationale of the crime of conspiracy. Since the intent in conspiracy reaches beyond the act accomplished and portends the commission of a further act, and so is the substance of the offense, it must be shown to be dangerous. The accused must be shown to have harbored a specific intent to do an unlawful act. This, at one time, may involve proving that he had the intent to defraud; at another, that he had the intent to steal; and at still another, the intent to violate a statute. Finally, in some instances, it may require proof that the defendant had the intent through concerted action with another to do an act to in.jure or oppress a third person, or an act to benefit the confederates to the prejudice of the public.

The case of People v. Porerell ${ }^{85}$ is illustrative of the principles and views just stated. The defendants, who were commissioners of charities, were indicted for conspiring not to advertise for supplies, as required by statute. They sought to show that they had acted in good faith, and that they did not know about the statute or that it was their duty to advertise. The trial court charged the jury that ignorance of the law, or an absence of intent to violate the statute, would not excuse them; that if they did the act which was prohibited, or omitted to do what was required, they were guilty. The Court of Appeals held that this instruction could not be sustained. Ordinarily, where a man does an act prohibited by law, the court observed, "he will not be allowed to say that he did not know" that the law existed. But in conspiracy, "The agreement must have been entered into with an evil purpose, as distinguished from a purpose simply to do the act prohibited in ignorance of the prohibition." 86

This doctrine was amplified in People v. Flack. ${ }^{87}$ The defendants, in that case, were charged in conspiracy with having falsely instituted and maintained an action for divorce in the name of the wife, without her knowledge or consent, against her husband. The indictment also alleged deception and imposition on the court in procuring the divorce by illegal and fraudulent practices. The decision turns on the instructions of the trial court. In making its charge to the jury, that court, among other things, said: "I feel bound to say to you, gentlemen, that this judgment-record is a record of a fraudulent divorce." After expanding that statement, it went on to say that ". . . ignorance on the part of the defendants, or any of them, of the meaning of this statute (conspiracy statute) cannot be a shield to them if you believe they have committed the acts." In reply to a question from the jury,

85. 63 N. Y. 88 (1875).

86. Id. at 92 .

87. I25 N. Y. 324,26 N. E. 267 , I I L. R. A. 807 (I89I) cited note 44 supra. 
it said, "a criminal intent is the doing of an unlawful act intending to do it." 88 In reversing the judgment, the Court of Appeals held that these, and other instructions given by the trial court, were erroneous, and that the question of the purpose and good faith of the defendants were factors which should have been considered by the jury. The formation of a common design by two or more persons, it observed, ". . . is never simpliciter a criminal conspiracy." "The mere fact," it went on to say, "that the conspiracy has for its object the doing of an act which may be unlawful, followed by the doing of such act, does not constitute the crime of conspiracy, unless the jury find that the parties were actuated by a criminal intent." An ". . . actual criminal or wrongful purpose," it pointed out, "must accompany the agreement, and if that is absent the crime of conspiracy has not been committed." "The character of the acts done, the design with which they were done, and whether fraudulent or not," it concluded, "were question for the jury." 89

The characteristics of the intent element are brought into even clearer relief in Commonwealth $v$. Gormley. ${ }^{90}$ The defendants were indicted in two counts. The first charged them with conspiring to violate specified sections of the election laws, by falsely and unlawfully making a record of the votes cast at an election on the official tally and return sheets before the time set by law and before the votes were legally ascertained. The second count charged the insertion of false figures on the tally sheets. They were found guilty on the conspiracy count. At the trial they admitted that they had inserted the figures on the tally sheets before the closing of the polls. They contended, however, that these insertions were made for candidates having no opposition. The trial court ruled that they had violated the plain provisions of the statute, and refused to permit them to show that they had acted in good faith and without fraudulent intent. In reversing this judgment, the Superior Court went immediately to the heart of the issue by posing a pivotal question. "May a defendant when charged with conspiracy," it inquired, "show that he had no intention to violate the law; that there was no corrupt motive?" If a material part of the crime is intention, it observed, ". . . the defendant may introduce any testimony that throws light on it." The court then went on to point out that the accused were indicted on two counts: on one, for making fraudulent entries, and under this they were not privileged to show intention or ignorance of law; on the other, for conspiracy, and 
under this they could prove their intentions and good faith. "Whenever the belief or intention is material," it concluded, "the defendant may directly testify as to what it was: . . ." 91

So far we have been dealing primarily with situations in which the intent of the defendants was to commit some criminal act. Criminal conspiracies are, however, not limited to such designs. ${ }^{92}$ Indeed, the boundaries of the crime are indistinct, and as we approach those boundaries, particularly where they seem to shade into the horizon, the intent element tends ever to become more elusive. Are combinations to commit torts and breaches of contract conspiracies, and if so, when? May confederacies to commit acts which if done by the parties separately would not be actionable ever constitute bases for conspiracy prosecutions? If the answer is affirmative, how are we in those situations to describe the criminal intent?

There is authority for saying that agreements to commit any tort are indictable conspiracies. Kenny limits this doctrine to torts that are malicious or fraudulent. ${ }^{93}$ The view is widely accepted that any combination to commit a tort which is defintely anti-social, as distinguished from one, for example, to commit a mere trespass or a minor personal injury, is indictable as a conspiracy. ${ }^{94}$ Confederacies to commit breaches of contract that are clearly anti-social or injurious to the public are likewise indictable. ${ }^{95}$ In these situations the principal difficulty is to determine what torts and what breaches of contract are involved. Once that is settled, once it is determined that the purpose was one for

91. Id. at 301, 303. See in accord: United States v. Jenks, 258 Fed. 763 (D. C. E. D. Pa. Igrg); State v. Flynn, 28 Iowa 26 (I869); Commonwealth v. The Sheriff, 8 Phila 645 (Pa. I87I). But cf. Chadwick v. United States, I4I Fed. 225 (C. C. A. 6th, 1905)) cited note 64 supra; Hamburg-American Steam Packet Co. v. United States, 250 Fed. 747 (C. C. A. 2d, I918).

"What is here announced is that, where the government relies upon circumstances to prove a conspiracy or the devising of a scheme and artifice to defraud, the case comes within that class where an intent different from the ordinary criminal intent must be shown." Fall v. United States, 209 Fed. 547,553 (C. C. A. 8th, I9I3).

"When, however, the prosecution is for conspiracy. . . there must be a 'corrupt intent,' which is interpreted to be the mens rea, the conscious and intentional purpose to break the law." Landen v. United States, 299 Fed. 75, 78 (C. C. A. 6th, 1924).

"Speaking in general terms, there must be an intent to do wrong. . . To constitute the criminal intent necessary to establish a conspiracy there must be both knowledge of the existence of the law and knowledge of its actual or intended violation." Commonwealth v. Benesch, 290 Mass. 125, I34-135, I94 N. E. 905, 910 (I935) cited note 50 supra.

92. The leading cases in the United States, the first extending the doctrine to a wrong which was not a crime and the other restricting it to purposes to do acts criminal in themselves or to be accomplished by criminal means, are: State v. Buchanan, 5 Har. \& J. 3I7 (Md. I82I) ; Commonwealth v. Eastman, 55 Mass. I89 (1848). See also, State v. Bacon, 27 R. I. 252, 6I Atl. 653 (I905).

93. KENNY, op. cit. sipra note 3 at 337. See also, HARRISON, op. cit. supra note I at $9 \mathrm{I}-96$.

94. Smith v. People, 25 III. I7 (I860); Mifflin v. Commonwealth, 5 W. \& S. 46I (Pa. I843) cited note 45 stipra. Cf. Commonwealth v. Eastman, 55 Mass. I89 (I848). cited note 92 supra; Rex v. Turner, 13 East 228, 104 Eng. Rep. R. 357 (K. B. I8Ix).

95. Vertue v. Lord Clive, 4 Burr. 2472, 98 Eng. Rep. R. 296 (K. B. 1769) cited note 4 supra. 
which it was criminal to agree, then what has been said above bearing on the averment in the pleadings and the proof of the intent applies with equal force here.

We come now to a group of decisions which very nearly defy classification and rationalization. These involve confederacies to do acts which are not unlawful in themselves and which would not be crimes if done by the parties separately. The problem in these situations is to determine when these combinations are criminal, and how to locate and describe the criminal intent. By what criteria, indeed, are we here to recognize that intent? Of these agreements, it has been said that their "vagueness renders it possible for judges to treat all combinations to effect any purpose which happens to be distasteful to them as indictable crimes, by declaring this purpose to be "unlawful'." 96 These combinations, it seems, may or may not be criminal depending on the intent or purpose in the minds of the parties. The question is not so much what the parties intended to do, or how they intended to do it, but why did they combine? Their guilt or innocence, to use the language often employed by the courts, is conditioned on the "motives" for which they combined, and where they contemplated more than one object, the stress is placed on their dominant "motive".97 When the act contemplated is lawful for an individual, an agreement to do it, according to a widely-accepted view, will make the parties liable to criminal prosecution when their intent (or their dominant intent) was to injure another, or to benefit the confederates to the prejudice of the public or the oppression of individuals. ${ }^{98}$

This doctrine was maintained in a leading English case. ${ }^{99}$ The plaintiffs brought a civil action for damages, alleging a conspiracy to prevent them from carrying on their trade. The plaintiffs and the defendants were rival shipowners trading between Europe and China. The complaint averred that the defendants, with the view to obtaining control of the homeward shipping trade and to prevent the plaintiffs from getting cargoes for their ships, entered into an agreement to offer merchants in China a rebate on tea shipped exclusively with the defendants. In upholding a judgment for the defendants, the Queen's Bench

96. KrNNy, op. cit. supra note 3 at 339 .

97. Commonwealth v. Carlisle, Bright. 36 ( $\mathrm{Pa}$. I82I) cited note 45 supra.

98. This study is proceeding on the theory that what the courts are stressing here is a specific intent and not a motive. The idea they are expressing, however, does approach the motive concept as that term is employed by courts in other connections. It probably is not motive in the sense the word is used by the psychologists. If we are dealing with motive, as distinguished from intent, in these cases we must note an exception to the well-recognized doctrine in the criminal law that motive is irrelevant. See, SAlMond, JURISPRUdenCE (9th ed. 1937) 523-524; Harno, Rationale of a Criminal Code (I937) 85 U. of PA. L. REv. 549, 555-558; State v. Ehlers, 98 N. J. L. 236, II9 At. I5 (1922) ; People v. Corrigan, 195 N. Y. I, 87 N. E. 792 (1909).

99. Mogul Steamship Co., Ltd. v. McGregor, 23 Q. B. D. 598 (I889) cited note 66 supra. 
Division observed it undoubtedly was true that some conduct not criminal in one individual may become criminal if done in concert by several. ${ }^{100}$ But to hold such combinations criminal, Bowen, L. J., pointed out, the act agreed to "between the defendants must have been the intentional doing of some act to the detriment of the plaintiffs' business without just cause or excuse." Would it be indictable conspiracy, he inquired, "to agree to drink up all the water from a common spring in a time of drought; [or] to buy up by preconcerted action all the provisions in a market or district in times of scarcity?" $\mathrm{He}$ then continued:

"Assume that what is done is intentional, and that it is calculated to do harm to others. Then comes the question, Was it done with or without 'just cause or excuse'? If it was bonâ fide done in the use of a man's own property, in the exercise of a man's own trade, such legal justification would, I think, exist not the less because what was done might seem to others to be selfish or unreasonable . . . But such legal justification would not exist when the act was merely done with the intention of causing temporal harm, without reference to one's own lawful gain, or the lawful enjoyment of one's own rights." 101

This view, beginning with Commonwealth ex rel. Chew v. Carlisle, ${ }^{102}$ decided in $182 \mathrm{I}$, has received repeated emphasis in both civil and criminal cases in the United States. The specific intent, it will be observed, lies in the common intent to injure or oppress others or to prejudice the public. Where the combination has for its object both a benefit to the parties and an injury to others, the problem resolves itself into an inquiry to find the dominant or ruling intent of the confederates. As stated by Justice Gibson in the Carlisle Case, "the motive for combining or, what is the same thing, the nature of the object to be attained as a consequence of the lawful act, is, in this class of cases, the discriminative circumstance." ${ }^{103}$ In a Wisconsin case, ${ }^{104}$ the offense charged was that the defendants had combined "wilfully and maliciously" to injure a newspaper publishing company in its business. Issue on the legality of the detention of the defendants on this charge was raised on habeas corpus. In an extensive opinion containing a thorough examination of previous decisions, the Supreme Court of Wisconsin, speaking through Justice Marshall, held that the complaint clearly charged a criminal offense. The court stressed the fact that an individual might

100. Cf. Huttley v. Simmons, [1898] I Q. B. I8I.

ror. Mogul Steamship Co., Ltd. v. McGregor, 23 Q. B. D. 598, 617, 618 (I889) cited note 66 supra.

ro2. Commonwealth v. Carlisle, Bright. 36 ( $\mathrm{Pa}$. I82I) cited note 45 sipra.

103. Id. at 39.

104. State v. Huegin, I Io Wis. I89, 85 N. W. 1046 (Igor). 
with purely "malicious motives" attract to himself another's customers and not be subject to legal action, but when he unites with others maliciously to injure "the business of another for the mere gratification, in whole or in part, of a desire to inflict such injury", he then renders himself liable to a criminal prosecution. The term "malicious injury", as employed in the language of the opinion, is the equivalent, according to the court's own definition, of "the infliction of a wrongful injury intentionally." 105

In New York this doctrine was applied in a decision ${ }^{106}$ on a charge brought under the conspiracy provisions of the Penal Code. ${ }^{107}$ The defendants, theatre managers, had agreed not to produce attractions controlled by rival interests and to produce only such attractions as had agreed not play in rival theatres. The evidence showed that this intent was to protect their own interests, but it was not denied that one effect of their action was to hamper their rivals. In granting a motion to dismiss the indictment, the Court of General Sessions said that it was the undoubted right of the defendants "to book, or refuse to book, any production that they saw fit, and to maintain and close any of their theatres at their option." It observed that there was "no motive on the part of the defendants to injure" others. The court recognized that the defendants' action "subjected their competitors to expense and inconvenience," but held that there was no criminal conspiracy, since the "motive was to promote their own business". ${ }^{108}$

\section{Conclusion}

The conception of criminal conspiracy as a device for law enforcement is a powerful instrument in the hands of prosecuting attorneys and the courts. It opens the way for the state to deal with individuals who have united into common designs to commit anti-social acts and

105. Id. at $26 \mathrm{I}-262,85 \mathrm{~N}$. W. 1066-1067. That this view is not accepted by all courts, see State v. Eastern Coal Co., 29 R. I. 254, 70 Atl. I (Igor).

106. People v. Klaw, 55 Misc. Rep. 72, 106 N. Y. Supp. 34I (Ct. Gen. Sess. 1907) cited note 45 supra.

107. The pertinent parts of the section under which this action was brought read, Penal Law, Gil. Crim. Code (I939) § 580: "If two or more persons conspire, . . [either] (5) to prevent another from exercising a lawful trade or calling, or doing any other lawful act, by force, threats, intimidation . . . or (6) to commit any act injurious .". to trade or commerce . - . each of them is guilty of a misdemeanor."

108. People v. Klaw, 55 Misc. Rep. 72, 8I-82, 106 N. Y. Supp. 34I, 347 (Ct. Gen. Sess. 1907) cited note 45 supra. To the same effect, see People v. Flynn, I14 App. Div. 578 , 100 N. Y. Supp. 31 (Ist Dep't 1906) cited note 45 sipra.

In Harris v. Thomas, 217 S. W. I068 (Tex. Civ. App. 1920), the petitioner, an osteopath, sought an injunction to prevent the defendants, members of a medical association, from interfering with his practice through excluding him from a hospital. The court affirmed an order dissolving a temporary injunction. The defendants, it said, "could, if they deemed it to the interest of medicine or surgery, or the welfare of humanity, agree among themselves not to assist appellant in surgery if they did so in good faith and with no intent to injure appellant." Id. at 1077. 
to forestall the commission of those acts. In addition, it is a convenient agency to bring into action against offenders when other avenues of establishing guilt are closed. But it also is a branch of jurisprudence which, as Fitzgerald, J., has observed, is to "be narrowly watched, to be jealously regarded, and never to be pressed beyond its true limits." 108

Owing to the elasticity of the crime and its vague boundaries, there can be no doubt that it presents serious potential dangers of abuse. The view is here advanced that these dangers would tend to be reduced once the basic principles of the crime and particularly the rôle of the intent element in it are fully understood. The gist of the crime lies not, as has often been said, in the agreement. The agreement is a factor, but it is no more than that. The gist of the crime is in the intent. It may be true that the possibilities for mischief are heightened through a number of individuals, as distinguished from one individual acting separately, uniting in a common design, but the grave danger lurks, nevertheless, in the intent of the confederates.

The impression seems to be current, as Judge Learned Hand has pointed out, ${ }^{110}$ that once a criminal concert is established, all are liable for everything one of the participants has done, and that prosecutors, as he has observed elsewhere, ${ }^{111}$ can sweep into the drag-net of conspiracy all those who have associated in any degree in the enterprise. There is peril, indeed, to the individual and to the public in that attitude, and there is peril, also, in the inherent vagueness in the definition of the crime. But bad practices can be discouraged and the dangers associated with the crime can be allayed if the courts will with regularity enforce the injunctions of the law of conspiracy in accordance with its basic principles. Conspiracy is an inchoate crime for which the essential act is slight. It involves an intent to commit a further act. It is the commission of that act which the state desires to prevent, and it is with the intent to commit that act that the state is concerned. The essence of the crime thus lies in the intent.

As a matter of procedure, it is imperative when a criminal conspiracy is charged that the state show, first, a common design and that the accused had the intent to become a party to that common design with knowledge of its implications, and, secondly, that the pleadings aver and the evidence definitely establish in conformity with the averment that the parties had a common intent to commit a specific anti-

Iog. Quoted by KENNY, op. cit. supra note 3 at 339 . 6I supra.

I10. United States v. Peoni, I00 F. (2d) 401,403 (C. C. A. 2d, I938) cited note

IIr. United States v. Falcone, Iog F. (2d) 579, 58I (C. C. A. 2d, I940) cited note 54 supra. 
social act. If that act involves a violation of positive law, the state must show that the accused intended to violate it, or entered into the common purpose with knowledge that a violation of law would result from the commission of the contemplated act. If the common purpose is to commit an act against public policy or public welfare, but not necessarily to violate a positive law, the state must show that the accused's intent, or at least his dominant intent, was to injure others or to prejudice the public. Thus circumscribed, we may agree with Justice Gibson's statement that he did not fear that the catalog of crimes would be enlarged unduly through the expansion of conspiracy since he found it was "never invoked except as a corrective of disorder which would else be without one, and as a curb to the immoderate power to do mischief which is gained by a combination of the means." 112

II2. Mifflin v. Commonwealth, 5 W. \& S. $46 \mathrm{r}, 464$ (Pa. I843) cited note 45 supra. 